\title{
Evaluation towards stud bulls with different mixed genotypes relating to somatotropin cascade genes by origin
}

\author{
Lenar Zagidullin ${ }^{1}$, Ilnaz Gilemhanov ${ }^{1}$, Rifat Khisamov ${ }^{1}$, and Sergey Tyulkin ${ }^{2}$ \\ ${ }^{1}$ Kazan State Academy of Veterinary Medicine named by N.E. Bauman, 420029 Kazan, Russia \\ 2 "FSC Food Systems named by V.M. Gorbatov" RAS, 109316 Moscow, Russia
}

\begin{abstract}
A preliminary evaluation towards a breeding value of the Holstein breeding bulls with different genotypes of somatotropin cascade genes is presented: pituitary transcription factor or growth hormone factor (PIT1), prolactin (PRL), somatotropin (GH), somatotropin releasing hormone (GHRH), insulin-like (IGF-1) in the conditions of the Republic of Tatarstan. The research studies the signs (indices) of milk productivity (milk yield and fat in milk) of the closest female ancestors of bulls with different genotypes of somatotropin cascade genes. Studies and analysis have shown that the bulls with the mixed genotypes ABAALLBBAA (10269 kg), AAAALLBBAB (4.13\%) and BBAALLABBB (9402 kg and $4.06 \%)$ had the highest and optimum evaluation by origin, judging by the bulls' pedigree (geneological) index. The frequency to meet bulls with the desired mixed genotypes was low and amounted to 4.28-5.71\%.
\end{abstract}

\section{Introduction}

At present, molecular genetics acts as the most diverse approaches and methods to be applied in animal husbandry, including testing breeding animals, their selection that depends on the genetic variants of productivity, diagnosis of hereditary diseases, research on the diversity and genetic structure of a herd, editing the genome and more [1-6].

Studies show that PIT1 gene (hypophisic transcription factor or growth hormone factor) is actively involved in animals development and also affects various physiological processes, including a hypophisic and mammary gland growth and development, expression of milk protein and milk secretion. Most researchers consider PIT1 gene to be responsible for the regulation of growth and development of breed cattle [7-10].

Significant differences in daily milk yield $(\mathrm{P}<0.05)$ of the Holstein breeding cows in favor of animals with AA genotype of PIT1 gene were revealed compared to the analogues of $\mathrm{AB}$ and $\mathrm{BB}$ genotypes. The results of studies showing off the genotypes association of PIT1 gene with indicators of milk productivity, conducted on the Holstein breeding cows in Vietnam, are similar to the results of other studies [11]. The same tendency (AA> $\mathrm{AB}>\mathrm{BB}$ ) in daily milk yield was found among cows of the local breed of Iraqi cattle with different genotypes of PIT1 gene [12].

The research results showed that there is a significant interaction between AA, AB, BB genotypes of PIT1 gene and a body weight of the local Iraqi and crossbreeding cows. AA genotype of PIT1 gene in cows led to an increase in an animal body weight [13].
Examining the effect of PRL gene (prolactin) on milk productivity of cows showed that A allele of this gene in cows of the Schwyz breed of American breeding, the Holstein breed of Turkish origin and the Gir and Kankrej of Indian origin (B. indicus) was associated with a higher milk yield compared to the analogues of BB genotype [15-17]. However, animals of the Gir and Kankrej breeds with BB genotype had a higher percentage of fat in milk compared to their peers with $\mathrm{AA}$ and $\mathrm{AB}$ genotypes of PRL gene [17].

The data obtained indicate the need to study PRL gene as a candidate, which affects the intensity and growth energy of cattle [18-19]. These data now can be used for early prediction of milk productivity. So in our earlier studies there was concluded that by the age of 18 months, the highest average daily gains were observed among heifers of the Holstein breed, bearing PRL gene allele in their genotype A compared to the peers with BB genotype. In the future, these first-calf heifers, with the largest body weight, had higher milk productivity.

In studies about pure-bred Simmental cattle, there were obtained the results indicating the highest yields, fat in milk and the amount of milk fat among cows with $\mathrm{VH}$ genotype of GH gene (somatotropin), which were superior in these indicators to their peers, who had LL and VL genotypes [20]. However, opposite results were obtained in the studies on the Kostroma breed cows. In this population the highest milk yield and the amount of milk fat were observed among animals with LL genotype of GH gene [21].

At the end of the experiments, the highest body weight was observed in calf bulls of the Hereford and Limousin breeds with LL genotype for $\mathrm{GH}$ gene, compared to the analogues of VV genotype. It is logical

\footnotetext{
Corresponding author: mehksavm@mail.ru
} 
that bulls with the LL genotype of GH gene in terms of average daily growth, absolute and relative growth rates exceeded peers with the genotype VV [22]. Their main research results and conclusions coincided with the data from other researchers [23-24].

Numerous studies conducted in different countries, including Turkey, show that there is a connection between the polymorphism of GHRH gene (somatotrophin-releasing of a hormone) and milk yield in various cattle populations [25].

Similar results in the studies about the population of the Holstein cows of Polish selection showed that cows with $\mathrm{BB}, \mathrm{AB}, \mathrm{AA}$ genotypes of GHRH gene had the largest, intermediate and least amount of milk fat and fat in milk, respectively [26].

Some studies note that genotypes and alleles of GHRH gene are associated with cattle meat productivity. A possible effect of genotypes of GHRH gene on the exterior estimator of buffalos in Indonesia was under examination but the connection between these indicators was not revealed [27]. However, in the studies on young bulls of the Limousine breed, such association with growth indicators was revealed. Thus, calves aged 210 days, bearing AA genotype of GHRH gene, were behind of peers with $\mathrm{AB}$ and $\mathrm{BB}$ genotypes in height at withers and sacrum [28].

The studies of the Holstein cows of Polish and Iranian origin showed that animals with $A B$ genotype in IGF-1 gene (insulin-like growth factor) significantly exceeded the analogues with AA and BB genotypes in such indicators as fat and protein in milk [29-30]. The similar studies that were carried out on cows of the Holstein breed of Polish selection showed that animals with IGFI / SnaBI AB genotype were characterized by the highest milk yield, the amount of milk fat and protein compared to peers with AA genotype. Whereas IGFI / SnaBI AA genotype was favorably distinguished by a high protein $(\mathrm{P} \leq 0.05)$, fat and lactose in milk [31].

The presented results demonstrated the association between BB genotype of IGF1 gene in cattle of the Angus breed and the highest indicators on growth and carcass quality. At the end of the experiment, the animals with this genotype had a higher body weight, and subsequently a heavier carcass, more deposition of subcutaneous fat and body length [32]. The similar results were obtained in the study on bulls of the Nellore, Canchim (5/8 Charolais $+3 / 8$ Zebu) breeds and mongrels of the Simmental $(1 / 2$ Nellore $+1 / 2$ Simmental) and Angus (1/2 Nellore $+1 / 2$ Angus) breeds [33].

Full provision with high-quality dairy raw materials to the processing industry enterprises is the key to the stable production of dairy products, such as fermentedmilk, cheese, canned, functional, hero-diet, etc. 34-35

The data presented above indicate about the relevance and prospects of assessing the origin of bulls belonging to the Holstein breed with different mixed genotypes PIT1, PRL, GH, GHRH, IGF1.

\section{Methods and materials}

The research study was carried out in the livestock of JSC Head breeding enterprise "Elite" of Vysokogorsky district, the Republic of Tatarstan. Blood samples were taken for the DNA analysis of allelic polymorphism within PIT1, PRL, GH, GHRH, IGF1 genes in 70 purebred and cross-breeding bulls from the Holstein breed. Blood from the animals was taken from the jugular vein (v. Jugularis), then it was put into tubes with $100 \mathrm{mM}$ EDTA so that the concentration was $10 \mathrm{mM}$.

The DNA was extracted from the biological material of cattle by using the combined alkaline method: $100 \mu \mathrm{l}$ of blood was added to the tube, $1 \mathrm{ml}$ of distilled water was added, it was shaken on a vortex and centrifuged at $10,000 \mathrm{rpm}$ for $10 \mathrm{~min}$. The supernatant was aspirated, and $50 \mu \mathrm{l}$ of $0.2 \mathrm{M} \mathrm{NaOH}$ was added to the precipitate, the mixture was shaken on a vortex until the suspension was clarified.

The resulting mixture was kept in a thermostat at 60 ${ }^{0} \mathrm{C}$ for 10 minutes. Next, $50 \mu \mathrm{l}$ of $1 \mathrm{M}$ Tris- $\mathrm{HCl}(\mathrm{pH} 8.0)$ was added to the tube and the mixture was shaken on a vortex. $500 \mu \mathrm{l}$ of $96 \%$ ethanol was added to the obtained homogenate, and the mixture was kept in the freezer at 20-16595-16696 C for 30 minutes. Further, the tubes with the contents were centrifuged at $12,000 \mathrm{rpm}$ for 10 minutes.

The supernatant was aspirated, and the precipitate was dried at 60-1659 0-1696 C for $12 \mathrm{~min}$ with an open tube. To the dried precipitate in a test tube, $100 \mu \mathrm{l}$ of 10 $\%$ ammonia was added, the mixture was shaken on a vortex and kept in a thermostat at 60-1659-01669 C for $10 \mathrm{~min}$, then it was shaken again on a vortex and kept in a thermostat at $60-16990-1669 \mathrm{C}$ for $10 \mathrm{~min}$. The resulting mixture was kept in a thermostat at $95{ }^{\circ} \mathrm{C}$ for 15 min with an open tube. The DNA preparation is ready for molecular genetic studies.

The animal genotype by the genes of the somatotropin cascade was determined by PCR-RFLP analysis: PIT1 [36], PRL [37], GH [38], GHRH [28], IGF1 [32].

The parental index of the bulls such as milk yield and fat in milk of the nearest female ancestors of the bulls was calculated by the formula:

$$
R I B=(2 M+M M+M F) / 4
$$

where $M$ are mothers, $M M$ are mothers of mothers, $M F$ are mothers of fathers.

The results obtained in the course of scientific research are processed by the biometric method.

\section{Results and discussion}

In the studied sample of pure-bred and cross-breeding bulls of the Holstein breed, 36 mixed genotypes were identified for genes PIT1, PRL, GH, GHRH, IGF1, of which 10 mixed genotypes had a frequency above $4.2 \%$.

The most frequently encountered mixed genotypes for genes PIT1, PRL, GH, GHRH, IGF1: 
BBAALLBBAB (7.14 \%), ABAALLBBAA (5.71\%), ABAALLBBBB (5.71\%), BBAALLBBAA $(5.71 \%)$, AAAALLBBAB $(4.28 \%)$, AAAALLBBBB $(4.28 \%)$, ABAALLBBAB (4.28 \%), ABAAVLBABAB (4.28\%) $4.28 \%)$, BBAAVLBBBB $(4.28 \%)$.

The frequency of other mixing genotypes was minimal. Thus, the frequency of 9 comprehensive genotypes ABAALLABAB, ABAAVLABBB, ABAAVLBBAA, ABAAVLBBAB, ABABLLBBAB, BBAALLABAB, BBAALLBBBB, BBABLLBBAB, BBABVLBBAB was only $2.86 \%$ and 17 integrated genotypes AAAALLABBB, AAAAVLBBAB, ABAALLAAAB, ABAALLABAA, ABAAVLABAA, ABABLLABAA, ABABLLABAB, ABABLLABBB, ABABLLBBAA, ABABVLABAB, ABABVLBBAA, BBAAVLBBAA, BBABLLAAAA, BBABLLABAA, BBABLLBBBB, BBABVLABAB, BBBBLLABBB are only $1.43 \%$, respectively.

The analysis of Table 1 shows that mothers of bulls with mixed genotypes ABAALLBBAA and BBAALLABBB for genes PIT1, PRL, GH, GHRH, IGF1 - $9777 \mathrm{~kg}$ and $9860 \mathrm{~kg}$ were the highest milkers, which is 171-1591 kg higher than mothers of bulls of other genotypes. Moreover, the difference between animals with mixed genotypes BBAALLABBB and AAAALLBBBB was significant and amounted to $1562 \mathrm{~kg}\left(\mathrm{P}=0.05^{*}\right)$ of milk. The fat in milk of mothers of bulls with the mixed genotype AAAALLBBAB exceeded their peers by $0.27-0.44 \%$.

From Tables 2 and 3 it can be seen that the highest rates of milk yield were for mothers of mothers (MM) and mothers of fathers (MF) of the bulls with mixed genotypes BBAALLBBAA and ABAALLBBAA (9467 and $13198 \mathrm{~kg}$ ), which is higher than that of the analogues with other mixed genotypes by $1141-3361 \mathrm{~kg}$ and $987-3668 \mathrm{~kg}$, respectively. Moreover, the difference between the animals with mixed genotypes BBAALLABBB and AAAALLBBBB was significant and amounted to $1562 \mathrm{~kg}\left(\mathrm{P}=0.05^{*}\right)$ of milk. Within the criteria - fat in milk, the highest rates were among mothers of mothers and mothers of bulls' fathers with mixed genotypes BBAALLABBB and ABAALLBBAA (4.37 and $4.43 \%$ ); they exceeded in this indicator individuals with other mixed genotypes by $0.24-0.77 \%$ and $0.03-0.53 \%$, respectively.

Table 1. Milk productivity of bull mothers with different mixed genotypes for PIT1, PRL, GH, GHRH, IGF1 genes

\begin{tabular}{|c|c|c|c|}
\hline Mixing genotype & $\mathrm{n}$ & milk yield, $\mathrm{kg}$ & fat, $\%$ \\
\hline AAAALLBBAB & 3 & $9070 \pm 385.5$ & $4.23 \pm 0.18$ \\
\hline AAAALLBBAB & 3 & $8298 \pm 449.4^{*}$ & $3.92 \pm 0.08$ \\
\hline ABAALLBBAA & 4 & $9777 \pm 1231.3$ & $3.79 \pm 0.04 *$ \\
\hline ABAALLBBAB & 3 & $8913 \pm 870.2$ & $3.92 \pm 0.13$ \\
\hline ABAALLBBBB & 4 & $9606 \pm 312.4$ & $3.96 \pm 0.06$ \\
\hline ABAAVLABAB & 3 & $8306 \pm 1351.0$ & $3.92 \pm 0.18$ \\
\hline BBAALLABBB & 3 & $9860 \pm 337.4$ & $3.87 \pm 0.05$ \\
\hline BBAALLBBAA & 4 & $8543 \pm 782.4$ & $3.92 \pm 0.19$ \\
\hline BBAALLBBAB & 5 & $8269 \pm 748.5$ & $3.85 \pm 0.10$ \\
\hline
\end{tabular}

Bulls origin evaluation, who had different mixed genotypes of the somatotropin cascade genes by the parental index (RIB), revealed that it varies among the animals under study. Thus, the parental index of the bulls with mixed genotypes ABAALLBBAA (10269 kg) and AAAALLBBAB $(4.13 \%)$ was higher in milk yield and in fat in milk compared to the analogues of other mixed genotypes by $867-1825 \mathrm{~kg}$ and $0.08-0.26 \%$, respectively. Optimal RIB indicators for milk yield and fat in milk were among the bulls with the mixed BBAALLABBB genotype (9402 $\mathrm{kg}$ and $4.06 \%)$ (Table 4).

Table 2. Milk productivity of bulls' mothers with different mixed genotypes for PIT1, PRL, GH, GHRH, IGF1 genes

\begin{tabular}{|c|c|c|c|}
\hline Mixed genotype & $\mathrm{n}$ & milk yield, $\mathrm{kg}$ & fat, $\%$ \\
\hline AAAALLBBAB & 3 & $6106 \pm 2589.0$ & $4.13 \pm 0.28$ \\
\hline AAAALLBBBB & 3 & $6458 \pm 535.3 *$ & $4.09 \pm 0.31$ \\
\hline ABAALLBBAA & 4 & $8326 \pm 1172.8$ & $3.84 \pm 0.06$ \\
\hline ABAALLBBAB & 3 & $7558 \pm 840.4$ & $3.95 \pm 0.21$ \\
\hline ABAALLBBBB & 4 & $7227 \pm 1493.6$ & $3.77 \pm 0.08$ \\
\hline ABAAVLABAB & 3 & $7353 \pm 704.3$ & $3.60 \pm 0.08$ \\
\hline BBAALLABBB & 3 & $7464 \pm 1075.0$ & $4.37 \pm 0.42$ \\
\hline BBAALLBBAA & 4 & $9467 \pm 966.8$ & $3.70 \pm 0.07$ \\
\hline BBAALLBBAB & 5 & $6332 \pm 1058.6$ & $3.90 \pm 0.05$ \\
\hline
\end{tabular}

Table 3. Milk productivity of mothers bulls fathers' with different mixed genotypes for PIT1, PRL, GH, GHRH, IGF1 genes

\begin{tabular}{|c|c|c|c|}
\hline Mixed genotype & $\mathrm{n}$ & milk yield, $\mathrm{kg}$ & fat, $\%$ \\
\hline AAAALLBBAB & 3 & $9530 \pm 490.5$ & $3.92 \pm 0.09$ \\
\hline AAAALLBBBB & 3 & $10129 \pm 54.7$ & $3.90 \pm 0.04$ \\
\hline ABAALLBBAA & 4 & $13198 \pm 2493.4$ & $4.43 \pm 0.39$ \\
\hline ABAALLBBAB & 3 & $10659 \pm 496.0$ & $4.40 \pm 0.33$ \\
\hline ABAALLBBBB & 4 & $11161 \pm 1446.8$ & $3.91 \pm 0.15$ \\
\hline ABAAVLABAB & 3 & $11136 \pm 2437.5$ & $4.20 \pm 0.40$ \\
\hline BBAALLABBB & 3 & $10426 \pm 242.3$ & $4.10 \pm 0.16$ \\
\hline BBAALLBBAA & 4 & $9987 \pm 638.4$ & $4.26 \pm 0.25$ \\
\hline BBAALLBBAB & 5 & $12211 \pm 2016.4$ & $3.90 \pm 0.03$ \\
\hline
\end{tabular}

Table 4. The parental index of bulls with different mixed genotypes for PIT1, PRL, GH, GHRH, IGF1 genes

\begin{tabular}{|c|c|c|c|}
\hline Mixed genotype & $\mathrm{n}$ & milk yield, $\mathrm{kg}$ & fat, $\%$ \\
\hline AAAALLBBAB & 3 & $8444 \pm 577.1$ & $4.13 \pm 0.14$ \\
\hline AAAALLBBBB & 3 & $8296 \pm 354.4$ & $3.96 \pm 0.11$ \\
\hline ABAALLBBAA & 4 & $10269 \pm 1462.7$ & $3.96 \pm 0.08$ \\
\hline ABAALLBBAB & 3 & $9011 \pm 706.2$ & $4.05 \pm 0.18$ \\
\hline ABAALLBBBB & 4 & $9398 \pm 273.2$ & $3.90 \pm 0.04$ \\
\hline ABAAVLABAB & 3 & $8775 \pm 1354.3$ & $3.91 \pm 0.19$ \\
\hline BBAALLABBB & 3 & $9402 \pm 488.6$ & $4.06 \pm 0.10$ \\
\hline BBAALLBBAA & 4 & $9135 \pm 726.9$ & $3.95 \pm 0.11$ \\
\hline BBAALLBBAB & 5 & $8771 \pm 1095.9$ & $3.87 \pm 0.06$ \\
\hline
\end{tabular}

\section{Conclusion}

Evaluation towards the breeding value of the bulls with different mixed genotypes of the somatotropin cascade genes (PIT1, PRL, GH, GHRH, IGF1) by origin showed that based on the parental index of the bulls, the closest female ancestors of bulls with mixed genotypes had better milk production ABAALLBBAA, 
AAAALLBBAB, BBAALLABBB, and the lowest in the analogues with mixed genotypes AAAALLBBBBB and BBAALLBBAB, respectively.

\section{References}

1. G.M.F. de Camargo, The role of molecular genetics in livestock production Animal production sci. 59(2), 201-206 (2018)

2. S.V. Tyulkin, T.M. Akhmetov, E.F. Valiullina, R.R. Vafin, Polymorphism of Somatotropin, Prolactin, Leptin, and Thyreoglobulin Genes in Bulls Russ. J. of Genetics: Applied Res. 3(3), 222-224 (2013)

3. N.S. Yudin, M.I. Voevoda, Molecular genetic marker of economically important traits in dairy cattle Russ. J. of Genetics 51(5), 506-517 (2015)

4. F.S. Sibagatullin, T.H. Faizov, G.S. Sharafutdinov, Sh.Z. Validov, R.R. Shaydullin, DNA technologies in animal husbandry Vestnik of Kazan State Agrar. Univer. 1(15), 130-132 (2010)

5. R.R. Shaydullin, G.S. Sharafutdinov, A.B. Moskvichtva, Protein content in the milk of first calf heifers of different CSN3 and DGAT1 genotypes during lactation Achievements of science and technology of AIC 33(5), 55-58 (2018)

6. S.V. Tyulkin, R.R. Vafin, L.R. Zagidulin, T.M. Akhmetov, A.N. Petrov, F. Diel, Technological properties of milk of cows with different genotypes of kappa-casein and betalactoglobulin Foods and Raw Materials 6(1), 154-162 (2018)

7. R. Majeed, A. Nadeem, M.E. Babar, M. Javed, S. Munir, A. Manzoor, POU1 transcription factor 1 DNA polymorphism in Nili Ravi buffalo Buffalo Bull. 32, 706-709 (2013)

8. S. Munir, A. Nadeem, M. Javed, M.E. Babar, T. Hussain, W. Shehzad, R.Z. Iqbal, S. Manzoor, Identification of Pit 1 gene variants in Sahiwal cattle of Pakistan Pakistan J. of Zoology 49(4), 1315-1319 (2017)

9. W.P.B. Putra, P.P. Agung, S. Said, The polymorphism in g.1256G>A of bovine pituitary specific transcription factor-1 (bPIT-1) gene and its association with body weight of Pasundan cattle $\mathrm{J}$. Indonesian Trop. Anim. Agric. 44(1), 19-27 (2019)

10. C. Zhang, B. Liu, H. Chen, X. Lan, C. Lei, Z. Zhang, R. Zhang, Associations of a HinfI PCRRFLP of POU1F1 gene with growth traits in Qinchuan cattle Anim. Biotech. 20, 71-74 (2009)

11. N.T.D. Thuy, N.T. Thu, N.H. Cuong, L.V. Ty, T.T.B. Nguyen, D.V.A. Khoa, Polymorphism of PIT-1 and Prolactin Genes and Their Effects on Milk Yield in Holstein Frisian Dairy Cows Bred in Vietnam Russ. J. of Genetics 54(3), 346-352 (2018)

12. A.K. Zabeel, W.G.M. Al-Bazi, H.A. Muhammed, Study the association of PIT1 gene polymorphism with milk yield and body weigh traits of local breed
Iraqi cattle in Kerbala province Biochem. Cell. Arch. 18(2), 1867-1871 (2018)

13. D.A. Hussain, Genetic structure analysis of PIT-1/ HinfI gene and its relationship with some productive traits in Iraqi and hybrid cows population (comparative study) World J. of pharmaceutical res. 5(7), 226-235 (2016)

14. M. Nasr, A. Awad, I. El Araby, Associations of leptin and pituitary-specific transcription factor genes polymorphisms with reproduction and production traits in dairy buffalo Reprod. domest. anim. 51(4), 597-603 (2016)

15. E. Alfonso, R. Rojas, J.G. Herrera, M.E. Ortega, C. Lemus, C. Cortez, J. Ruiz, R. Pinto, H. Gomez, Polymorphism of the prolactin gene (PRL) and its relationship with milk production in American Swiss cattle African J. of biotechnol. 11(29), 7338-7343 (2012)

16. S.B. Oguzkan, A.S. Bozkurt, A study on the effect of Prolactin gene variants on milk production traits of Holstein cattle Russ. J. of genetics 55(4), 480-486 (2019)

17. J.B. Patel, J.B. Chauhan, Polymorphism of the prolactin gene and its relationship with milk production in gir and kankrej cattle J. of natural sci., biology and med. 8, 167-170 (2017)

18. M.L. Looper, S.G. Black, S.T. Reiter, Z.B. Johnson, C.F. Rosenkrans, R. Okimoto, M.A. Brown, Identification of polymorphisms in the enhancer region of the bovine Prolactin gene and association with profitability traits of beef cattle Professional animal scientist 26(1), 103-108 (2010)

19. L. Meyer, J. Powell, B. Rutz, M. Looper, A.H. Brown, C. Rosenkrans, Associations of single nucleotide polymorphisms in the bovine prolactin gene with phenotypic traits in beef cattle Agri Gene. 5, 7-11 (2017)

20. T. Bekseitov, R. Abeldinov, T. Asanbaev, G. Dzhaksybaeva, Expression of candidate genes of lipid metabolism in the Kazakhstani breeding Simmental cattle Annals of agrar. sci. 15, 443-446 (2017)

21. A.V. Percun, I.V. Lazebnaya, S.G. Belokurov, M.N. Ruzina, G.E. Sulimova, Polymorphism of CSN3, BGH and BPRL genes in connection with milk quality traits in Kostroma cattle breed Fundam.1 res. 11, 304-308 (2012)

22. T.A. Sedykh, E.A. Gladyr, V.R. Kharzinova, R.S. Gizatullin, L.A. Kalashnikova, Effect of $G H$ and DGAT1 gene polymorphism on feeding Qualities of bull calves Russ. Agricult. Sci. 43(1), 48-52 (2017)

23. V.A. Soloshenko, G.M. Goncharenko, A.A. Dvoryatkin, B.O. Inerbaev, T.S. Goryacheva, N.B. Grishina, Effect of thyroglobulin and somatotropin gene polymorphism on the intensity of growth in cattle Issues of biology of production animals 1, 55-58 (2011) 
24. K. Tatsuda, K. Oka, A. Iwamoto, Y. Kuroda, H. Takeshita, H. Kataoka, S. Kouno, Relationship of the bovine growth hormone gene to carcass traits in Japanese black cattle J. Anim. Breed. Genet. 125(1), 45-49 (2008)

25. M. Akkaya, B. Akyüz, Türkiye'de Yetiştirilen Holştayn Irkı Siğırlarda GHRH ve PRL Gen Polimorfizmleri ile Süt Verimi Arasındaki Illişkinin Araştırılması KSÜ Tarım ve Doğa Derg. 22(5), 763-771 (2019)

26. M. Szewczuk, S. Zych, R. Chaberski, Effect of growth hormone-releasing hormone gene polymorphism (GHRH/HaeIII) on milk performance in Polish holstein-friesian cows Acta univ. agric. et silvic. Mendel. Brun. LVI (4), 177-182 (2008)

27. K. Eriani, R. Rahmi, I. Jamil, R. Rosnizar, Body size characteristics and polymorphism in GH and GHRH genes of Simeulue Buffalo of Aceh, Indonesia Biodiversitas 20(1), 236-242 (2019)

28. A. Dybus, M. Kmiec, Z. Sobek, W. Pietrzyk, B. Wisniewski, Associations between polymorphisms of growth hormone releasing hormone (GHRH) and pituitary transcription factor 1 (PIT1) genes and production traits of Limousine cattle Arch. Tierz., Dummerstorf. 46(6), 527-534 (2003)

29. E. Siadkowska, L. Zwierzchowski, J. Oprzadek, N. Strzalkowska, E. Bagnicka, J. Krzyzewski, Effect of polymorphism in IGF-1 gene on production traits in Polish Holstein-Friesian cattle Anim. Sci. Papers and Reports 24(3), 225-237 (2006)

30. E. Bonakdar, H.R. Rahmani, M.A. Edriss, B.E. Sayed-Tabatabaei, G.R. Ghorbani, Polymorphism of insulin-like growth factor I in Iranian Holstein cows British Society of Anim. Sci. 1, 210 (2008)

31. E. Czerniawska-Piatkowska, M. Szewczuk, E. Chocilowicz, B. Cioch, The comparison of yield, nutritive value and technological usefulness of milk from Holstein-Friesian cows of Black-and-White strain depending on the IGFI/SnaBI and IGF1R/HinfI polymorphisms Electronic J. of Polish. Agricult. Univer. 16(3) (2013)

32. W. Ge, M.E. Davis, H.C. Hines, K.M. Irvin, R.C.M. Simmen, Association of genetic markers with blood serum insulinlike growth factor-I concentration and growth traits in Angus cattle J. Anim. Sci. 79, 1757-1762 (2001)

33. R.A. Curi, H.N. de Oliveira, A.C. Silveira, C.R. Lopes, Association between IGF-I, IGF-IR and GHRH gene polymorphisms and growth and carcass traits in beef cattle Livestock production sci. 94, 159-167 (2005)

34. A.G. Galstyan, A.N. Petrov, I.A. Radaeva, O.O. Sarukhanyan, A.N. Kurzanov, A.P. Storozhuk, Scientific bases and technological principles of the production of gerodietetic canned milk Probl. of Nutrition 85(5), 114-119 (2016)

35. A.N. Petrov, A.G. Galstyan, I.A. Radaeva, S.N. Turovskaya, E.E. Illarionova, V.K. Semipyatnyi, S.A. Khurshudyan, L.M. DuBuske, L.N. Krikunova, Indicators of quality of canned milk: Russian and international priorities, Foods and Raw Mater. 5(2), 151-161 (2017)

36. J. Woollard, C.B. Schmitz, A.E. Freeman, C.K. Tuggle, Rapid communication: HinfI polymorphism at the bovine Pit-1 locus J. of Anim. Sci. 72, 3267 (1994)

37. A. Dybus, W. Grzesiak, H. Kamieniecki, I. Szatkowska, Z. Sobek, P. Blaszczyk, E. Czerniawska-Piatkowska, S. Zych, M. Muszynska, Association of genetic variants of bovine prolactin with milk production traits of Black-and-White and Jersey cattle Arch. Tierz. 48(2), 149-156 (2005)

38. D.F. Gordon, D.P. Quick, C.R. Erwin, J.E. Donelson, R.A. Maurer, Nucleotide sequence of the bovine growth hormone chromosomal gene Mol. Cell. Endocrinol. 33, 81-95 (1983) 